\title{
Does the Utilization of Information Communication Technology Promote Entrepreneurship: Evidence from Rural China
}

\author{
William A. Barnett \\ Department of Economics \\ University of Kansas, Lawrence \\ and Center for Financial Stability, \\ New York City \\ and IC $^{2}$ Institute, \\ University of Texas at Austin \\ williamabarnett@gmail.com \\ Mingzhi Hu \\ Department of Investment \\ School of Public Economics and Administration \\ Shanghai University of Finance and Economics \\ Shanghai, China \\ hu_mingzhi@outlook.com \\ Xue Wang* \\ Department of Finance \\ College of Economics \\ Jinan University \\ Guangzhou, China \\ wangxue1207@hotmail.com
}

March 18, 2018

\begin{abstract}
Impacts on the probability of transition to entrepreneurship in rural China associated with the utilization of information communication technology (ICT) are estimated using longitudinal data from the China Family Panel Studies (CFPS) survey. We identify cell phone ownership and internet use as proxy variables for ICT utilization and find that cell phone ownership and internet use have positive impacts on entrepreneurship. After controlling for observables and time and regional fixed effects, cell phone users (internet users) are 2.0 (6.4) percentage points more likely to engage in entrepreneurship than the others. Considering that the average entrepreneurship rate for rural households is only $9.5 \%$ in the sample, the influence of cell phone ownership and internet use are very strong in the economic sense. Our results are robust to unobservable individual characteristics, model misspecification, and reverse causality of entrepreneurship to ICT utilization. Evidence also suggests that social network and information and knowledge acquisition play the mediating roles in the impact of ICT utilization on entrepreneurship.
\end{abstract}

Key words: ICT; social network; information acquisition; entrepreneurship

JEL: D10; M51; Q55

*Corresponding author. 


\section{Introduction}

Since entrepreneurial dynamism is broadly recognized as a driving force of innovation and an engine for economic growth, understanding the determinants of entrepreneurial ventures is important for public policy analysts, economic forecasters, and business managers. See., e.g., Acs, Desai and Hessels (2008), Carree and Thurik (2010), Gries and Naudé (2010), and Schumpeter (1951). Earlier studies have examined the determinants of entrepreneurship from many aspects, such as institutional, financial constraint, social resources, and individual characteristics. See., e.g., Gibson, Kozmetsky and Smilor (1992), Blanchflower and Oswald (1998), Chowdhury, Audretsch and Belitski (2015), Cowling and Taylor (2001), Disney and Gathergood (2009), Holtz-Eakin, Joulfaian and Rosen (1994), and Taylor (2001). The utilization of information communication technology (ICT) has a positive effect on economic growth. See., e.g., Meijers (2014) and Yoon, Yun, Lee, and Phillips (2015). However, less attention has been paid to the influence of ICT utilization on entrepreneurship. This paper aims to contribute towards filling this research gap.

We contribute to the existing literature in the following ways. First, we examine the relationship between the ICT utilization and entrepreneurship and show that the ICT utilization significantly promotes entrepreneurship. Using longitudinal data from the China Family Panel Survey (CFPS) in 2014 and 2016, we find that after controlling for observables and time and region dummies, the probability of transition to entrepreneurship for cell phone (or internet) users is on average 2.0 (6.4) percentage points higher than that for those who do not use cell phones (or the internet). Considering that the average entrepreneurship rate for rural households is $9.5 \%$ in the sample, the influence of cell phone ownership (internet use) on entrepreneurship is very 
strong. The estimated coefficient of 2.0 (6.4) for cell phone (internet) users amounts to a 21.05 (67.39) percent increase in entrepreneurship rate relative to the national average. These results are robust to unobservable individual characteristics, model misspecification and reverse causality of entrepreneurship to ICT utilization.

Second, we sum up and specify two mechanisms revealing how the ICT utilization affects entrepreneurship. The first mechanism is that ICT utilization helps to expand individual's social network, and thus promotes entrepreneurship. The information and knowledge acquisition mechanism works through the increase in ability of entrepreneurial opportunity identification for the use of ICT products and applications. These two mechanisms are well specified empirically. Specifically, we find that cell phone and internet users are associated with stronger social networks and more information and knowledge acquisition than the others.

The rest of the paper is organized as follows. Section 2 reviews related studies on the mechanisms that ICT utilization works on entrepreneurship. Section 3 introduces the data and variables. Section 4 reports empirical results on the role of ICT utilization in entrepreneurship. Section 5 conducts several robustness checks. The last section concludes the article.

\section{Literature Review: Mechanisms}

There are several mechanisms underlying why ICT utilization would impact entrepreneurship, as suggested in the literature. These mechanisms fall into two categories: (i) social network mechanism and (ii) information and knowledge acquisition mechanism.

\subsection{Social Network Mechanism}


ICT utilization helps to expand individual's social network and thus promotes entrepreneurship. The interpersonal communication is an important way for people to obtain social and economic resources and maintain and develop social networks (Cho et al., 2007). Face-to-face contact is the traditional means of interpersonal communication, while communication through the use of socially interactive technology, such as phone calls and text messages, is becoming increasingly popular (Pierce, 2009). Technological communication is more convenient and significantly reduces face-to-face interaction with the development of ICT (Erwin et al., 2004). Therefore, ICT utilization can enlarge individual's social network by more communication with others. The social network, commonly known as social relation, is a network of friends and acquaintances linked by formal and informal connections between members. This positive effect of ICT utilization on social network is especially prominent in rural areas of developing countries for three reasons. First, the development and utilization of ICT in rural regions are backward; second, rural people's social network is more narrow than their urban counterparts, since social network in rural regions is usually based on blood relationship and friendship ties; third, rural regions have much lower population densities. It is hard for rural people to contact with their social network members, who live far always from them with a weak transportation infrastructure.

A number of studies demonstrate positive effects of social network on entrepreneurship. The main reason is that social network helps potential entrepreneurs obtain financing. Potential entrepreneurs are often wealth constrained, and obtaining external financing is central for entrepreneurship in an imperfect credit market. See., e.g., Kozmetsky (1985), Paulson and Townsend (2004), and Djankov et al. (2006). Information asymmetry between potential entrepreneurs and investors is the key issue 
of financing difficulty. However, social network can overcome the problem of information asymmetry through mechanisms of social obligation between connected parties as well as information transfer through social communication. See., e.g., Venkataraman (1997), Shane and Venkataraman (2000), and Shane and Cable (2002). It is hard for rural people to obtain adequate entrepreneurial capital from formal financial institutions because of discrimination and limited collateral (Bai, Lu and Tao, 2006). Thus, informal financing through social network is the main form in rural areas.

\subsection{Information and Knowledge Acquisition Mechanism}

The ability to discover entrepreneurial opportunities, which are those situations in which the revenue exceeds the costs of investment in product markets or factor markets, is the preliminary step for the entry into entrepreneurship. Shane and Venkataraman (2000) suggest two broad categories of factors that are necessary to the opportunity discovery: (i) the possession of the prior information that triggers an entrepreneurial conjecture and (ii) the cognitive properties that find its value.

The information and knowledge acquisition mechanism works through the increase in entrepreneurial opportunity identification ability for the use of ICT products and applications. ICT products and applications provide abundant information conducive to identifying opportunities. Although the phenomenon of entrepreneurial opportunities is objective, the process of discovering them is subjective and needs adequate prior information (Shane and Venkataraman, 2000). The existence of entrepreneurial opportunities depends on the distribution of information (Companys and McMullen, 2007). For example, according to the results from spin-glass simulations to the dynamical process of entrepreneurial decision, Minniti (2004) finds that more acute agents are associated with a higher likelihood of entrepreneurial engagement. However, even highly acute agents exhibit few entrepreneurial behaviors, if information is equally 
distributed. Entrepreneurial engagement is shown to increase and concentrate geographically, if information is not equally distributed. People who use the ICT products or services can obtain more information, and thus they may have higher probabilities of becoming entrepreneurs than those who do not.

Knowledge learned from ICT products and applications can increase the cognitive properties necessary to entrepreneurship. Financial literacy, defined to be the basic understanding of economic and financial knowledge and the capability to use that knowledge and other instruments to manage financial resources effectively, is especially important for entrepreneurship (Hung, Parker and Yoong, 2009). For example, Oseifuah (2010) documents that entrepreneurial activities often occur in regions where people have high levels of financial literacy. By comparing the outcomes of treatment groups receiving additional entrepreneurship teaching of business knowledge with those of control groups that do not, Karlan and Valdivia (2011) find that entrepreneurship teaching can increase individual's entrepreneurial practices and revenues.

\section{Data and Variables}

\subsection{The Data Source}

This paper uses the data from the China Family Panel Survey (CFPS henceforth) in 2014 and 2016. CFPS is a nationwide household survey, funded by the Chinese government and managed by Peking University. Since regional differences are extremely large in Chinese society, this survey implements a probability proportional to size sampling (PPS) design with implicit stratification. The baseline survey of CFPS started in 2010 and covers around 15,000 households and 30,000 individuals from 25 provinces/cities/autonomous regions, excluding Hong Kong, Macao, Taiwan, Xinjiang, 
Xizang, Qinghai, Inner Mongolia, Ningxia, and Hainan. Since the population of these 25 regions constitutes almost 95\% of the total population of China, this longitudinal survey is nearly nationally representative. Three waves of surveys were conducted in 2012, 2014 and 2016, respectively, after the preliminary survey.

This paper chooses the CFPS of 2014 and 2016, because this survey begins to incorporate the module of mobile phone and internet. By using the unique identification code of each individual, we construct a panel dataset by matching samples in CFPS 2016 with those who also appeared in CFPS 2015. We restrict our sample to rural individuals aged between 20 and 60 years old, because analysis in this paper focuses on individual's working choice. We also exclude observations with missing value. The final dataset contains a total of 15,702 observations in 25 provinces.

\subsection{Variables}

The dependent variable in our paper is an indicator variable of an entrepreneur. We define a person as an entrepreneur, if he/she is a self-employed worker or private enterprise owner, as in $\mathrm{Li}$ and $\mathrm{Wu}$ (2014). The CFPS incorporates information about whether the respondent engages in self-employed business, including individually operated businesses and private enterprises. Entrepreneurship can be categorized into two types: self-employment without employees (necessity-based entrepreneurship) and entrepreneurship with employees (opportunity-based entrepreneurship). These two types of entrepreneurship differ in many aspects, such as entrepreneurial purpose, requirements for capacity of management, and availability of entrepreneurial assets. Interesting findings may be found by investigating the relationship between ICT and these two types of entrepreneurship, respectively. However, we cannot explore that separation, because of limited data availability. This research topic deserves further investigation. 
The independent variables are several measures regarding the utilization of ICT in the CFPS. In particular, the use of cell phone and internet technology is examined from three respects: first, whether the interviewee uses mobile phone (coded 1 if yes, and 0 if no); second, what is the mobile phone fee per month; third, whether the respondent uses the internet (coded 1 if yes, and 0 if no).

We use two mediating variables to explain the relationship between the utilization of ICT and the entry into entrepreneurship. The first is the social network, which is measured by the total amount of money that the household receives and expends in gifts and cash related to important events, such as weddings, children births, and birthday celebrations. Another is the information acquisition. There is a question that asks the respondent to measure the importance of the internet for information acquisition. The respondent codes data on a 1-5 scale, coded from 1 if 'very unimportant' to 5 'very important'.

We also include many individual and household variables that could impact a person's decision to entrepreneurial engagement, such as education, age, marital status, gender, hukou system registration, political status, and household wealth, as suggested in Schmalz et al. (2017), Zhang and Pan (2012), Yueh (2009), and Li and Wu (2014). In China, hukou is a unique registered residency in the government monitoring system (Chen and Han 2014). Every household in China is required to have a registered residency with a local government authority, either urban or “non-agricultural” hukou or rural or "agricultural” hukou (Tang and Coulson, 2017). Many resources and benefits, including access to health care, free public education, housing, and better access to jobs, are restricted to local residents with urban hukou (Au and Henderson, 2006; Glaeser et al., 2016). 
Table 1 provides the summary statistics and definitions of variables. From Table 1 we can see that the fraction of entrepreneurs is around 9.5\% in rural China, a much lower percentage than in urban regions (16.3\%). The cell phone ownership rate reaches almost $90 \%$ in the sample, while the percentage of internet user is only $16.7 \%$.

\section{* Table 1 is inserted into here *}

It is useful to examine the general patterns seen between ICT and entrepreneurship by comparing the entrepreneurship rate between cell phone/internet users and others. Figure 1 shows that the average entrepreneurship rate for cell phone owners is $9.81 \%$ versus $6.52 \%$ for others, suggesting cell phone owners are more likely to enter into entrepreneurship. The total of payments and receipts related to the maintenance of social relations is $6,446.52$ yuan for cell phone users, which is $1,230.45$ yuan higher than for people who do not use a cell phone. These findings suggest that the positive influence of cell phone ownership on entrepreneurship may operate thorough its extension effect on social networking. The average entrepreneurship rate and use of the internet for information and knowledge acquisition are depicted in Figure 2. We can see that internet users are 7.45 percentage points more likely to engage in entrepreneurship and attach more importance to the internet for obtaining information. The utilization of the internet may promote entrepreneurship by helping to acquire information and knowledge necessary to discover entrepreneurial opportunities.

\footnotetext{
* Figure 1 is inserted into here *

* Figure 2 is inserted into here *
} 


\section{Empirical Findings}

Below, we introduce the econometric models for the following empirical investigations, present an overall picture regarding the effect of ICT utilization on entrepreneurship, and offer explanations of the findings from the perspective of social network and information acquisition. We choose the use of cell phone and internet as the proxy variables for the utilization of ICT. The regression with binary code of entrepreneurship is estimated with the standard probit model and the regression with the continuous outcome is estimated with the ordinary least squares (OLS) model.

\subsection{Cell Phone Ownership, Social Network and Entrepreneurship}

In the first stage, we examine the influence of cell phone ownership on entrepreneurship and test whether this influence works through the effect of expanding the social network.

\subsubsection{Cell Phone Ownership and Entrepreneurship}

We use the following regression model to examine the relationship between cell phone ownership and entrepreneurship:

$\operatorname{Pr}\left(\right.$ Entrepreneur $\left._{i j t}=1\right)=G\left(\beta_{0}+\beta_{1}\right.$ Cell phone owner $\left.{ }_{i j t}+\delta X+\tau_{t}+\varphi_{j}+\varepsilon_{i j t}\right)$

where the dependent variable, Entrepreneur ${ }_{i j t}$, is an indicator variable of an entrepreneur for individual $i$ in province $j$ and year $t$. It is specified as a function of cell phone ownership (Cell phone owner ${ }_{i j t}$ ) and control variables $(X)$. In addition, year dummies $\left(\tau_{t}\right)$, province dummies $\left(\varphi_{j}\right)$, and an error term $\left(\varepsilon_{i j t}\right)$ are included in the econometric model. The function $\mathrm{G}(\cdot)$ with a value between 0 and 1 is set as the normal cumulative distribution. 
Table 2 is from a separate regression, gradually increasing the number of controlled variables from left to right (exception column (4)). We begin with the simplest specification by controlling for cell phone ownership only, and report the results in column (1) of Table 2. Without controlling for other observables, the marginal effect indicates that cell phone users are on average 3.3 percentage points higher than people who do not use cell phones. The difference is significant at the $1 \%$ level.

* Table 2 is inserted here *

As a first step toward measuring the effect of cell phone ownership on entrepreneurship, in Specification 2 we control for individual and household characteristics, including education, age, marital status, gender, hukou, political status, and household wealth. See Table 1 for the definitions of variables. The results are reported in column (2) of Table 2. The marginal effect on the transition to entrepreneurship of cell phone ownership becomes 2.2 percentage points, a 1.1 percentage points decrease from that in column 1 , but remains significant at the $1 \%$ level.

In Specification 3, we further control for year and location fixed effect. The results are reported in column (3) of Table 2. After controlling for the aggregate time-series trends and time-invariant regional unobservables, the difference between internet users and non-internet users in entrepreneurship rate narrows further, from 2.2 to 2.0 percentage points. Considering that the average entrepreneurship rate for rural households is $9.5 \%$ in the sample, the influence of cell phone ownership on entrepreneurship is very strong. The estimated coefficient of 2.0 for cell phone user in column (3) of Table 2 amounts to a 21.05 percent increase in entrepreneurship rate relative to the national average. 
In Specification 4, we concentrate on samples of cell phone owners and see whether the expenditure on cell phone fees increases entrepreneurship. As shown in column (4) of Table 2, the coefficient of cell phone expenses is statistically significant and positive. The more the expenditure on cell phone fees, the stronger the probability of engaging in entrepreneurship. The likelihood of entrepreneurial engagement increases with the intensity of cell phone use.

\subsubsection{The Mediating Role of Social Network}

From Table 2, we can see that owning a cell phone can increase the likelihood of individuals becoming entrepreneurs. We now use the following model to explore the expansion effect on entrepreneurship of increased social networking from cell phone ownership:

Social network $_{i j t}=\beta_{0}+\beta_{1}$ Cell phone owner ${ }_{i j t}+\delta X+\tau_{t}+\varphi_{j}+\varepsilon_{i j t}$

where Social network ${ }_{i j t}$ represents the social network of individual $i$. We measure it as the total amount of household expenses and receipts related to the maintenance of social relations. The key estimate is the value of $\beta_{1}$, which measures the relationship between individual's social network and the probability of entrepreneurial engagement.

Table 3 reports the regression results from Equation (2), which illustrates how owning a cell phone expands the social network. The results show that the total amount of expenses and receipts related to the maintenance of social relations for cell phone owners is $22.9 \%$ more than that for the others. In comparison with people who do not use cell phone, those who own a cell phone likely have a stronger social network.

\footnotetext{
* Table 3 is inserted here *
} 
Since we have observe a positive effect of cell phone ownership on social network, the final step to test the mediating role of social network is to examine whether the social network impacts entrepreneurship. We estimate the model as follows:

$\operatorname{Pr}\left(\right.$ Entrepreneur $\left._{i j t}=1\right)=G\left(\beta_{0}+\beta_{1}\right.$ Social network $\left._{i j t}+\delta X+\tau_{t}+\varphi_{j}+\varepsilon_{i j t}\right)$

where Entrepreneur $_{i j t}$ is an indicator variable of entrepreneurs and Social network $k_{i j t}$ denotes individual $i$ 's social network. Other control variables are the same as those in Equation (1).

We report the results from equation (3) in Table 4. The coefficient of social network in columns (1) to (3) of Table 4 remains positive and is statistically significant at the $1 \%$ level, indicating that a strong social network increases individual's entrepreneurship engagement. These findings demonstrate the mediating role of social network in the impact of cell phone ownership on entrepreneurship.

* Table 4 is inserted here *

\subsection{Internet Use, Information and Knowledge Acquisition, and}

\section{Entrepreneurship}

In the second investigation, we examine the influence of internet use on entrepreneurship and test whether this influence works through the effect of more information acquisition.

\subsubsection{Internet Use and Entrepreneurship}


We first investigate the impact of internet use on the probability of being engaged in entrepreneurial activity by estimating the following regression:

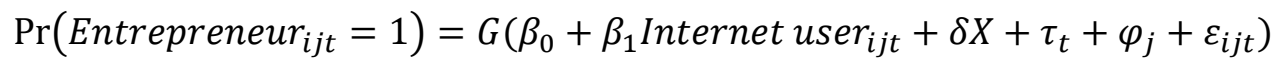

where Internet user $_{i j t}$ is an indicator variable of people who use the internet. We report the results from equation (4) in Table 5.

\section{* Table 5 is inserted here *}

From Table 5, we can see that after controlling for observables, internet users are 6.4 percentage points more likely to engage in entrepreneurship than people who do not use the internet. The estimated coefficient of 0.064 implies a 67.39 percent increase in the probability of entrepreneurial engagement for the internet users relative to the national average. These results suggest that the internet has a strong positive effect on entrepreneurship.

\subsubsection{The Mediating Role of Internet Use}

The results in Table 5 suggest that internet users have a higher probability of becoming entrepreneurs than the others. We now want to see the mechanism by which internet use affects entrepreneurship. As we have discussed, information and knowledge acquisition plays an intermediate role in the casual pathway from ICT utilization to entrepreneurship. We examine the impact of internet use on the information and knowledge acquisition using the following regression:

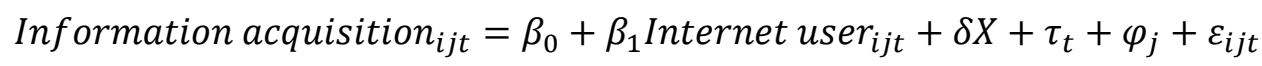




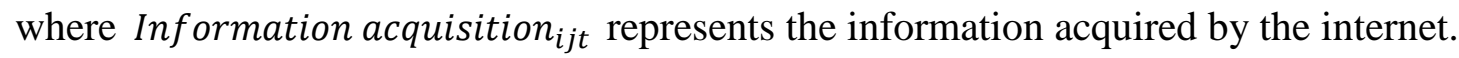
This is an ordinal variable with a scale from ' 1 ' to ' 5 '. The code of ' 1 ' means that the internet is very unimportant for information and knowledge acquisition and '5' means very important.

The results from equation (5), as displayed in Table 6, suggest that internet users attach more importance to the internet for information and knowledge acquisition than people who do not use the internet, and the difference is significant at the $1 \%$ level. This finding suggests that the internet helps to expand the channel of information acquisition.

\section{* Table 6 is inserted here *}

Results in Table 6 demonstrate that the use of internet enhances information acquisition. We next examine whether information and knowledge acquisition increases the probability of being an entrepreneur by running the following regression:

$\operatorname{Pr}\left(\right.$ Entrepreneur $\left._{i j t}=1\right)=G\left(\beta_{0}+\beta_{1}\right.$ Information acquisition $\left._{i j t}+\delta X+\tau_{t}+\varphi_{j}+\varepsilon_{i j t}\right)$

Columns (1) to (3) of Table 7 report the results from Equation (6). The results show that the coefficient of Information acquisition Ijt $_{\text {is }}$ is statistically significant and positive. People who consider the internet to be important in gaining information are more likely to be entrepreneurial than their counterparts who do not. These findings confirm that the internet has a positive effect on entrepreneurship as an important channel to obtain information necessary to entrepreneurial engagement.

\footnotetext{
* Table 7 is inserted here *
} 


\section{Robustness Check}

We have observed that the utilization of ICT can increase the probability of transition to entrepreneurship. However, a number of alternative explanations could possibly explain this pattern. In this section, we attempt to immunize our results from the following three potential alternative reasons: (i) unobservable individual characteristics, (ii) model misspecification, and (iii) reverse causality of entrepreneurship to ICT utilization.

\subsection{Unobservable Individual Characteristics}

Results from Equation (1) and (3) may be biased by omission of unobservables at the individual level. For example, entrepreneurial ability or attitude towards venturing investment can be important to entrepreneurial engagement. By including the individual level unobservables $\left(U_{i}\right)$, we rewrite Equation (1) and (3) as Equation (1') and (3') as follows:

$$
\begin{aligned}
& \operatorname{Pr}\left(\text { Entrepreneur }_{i j t}=1\right)=G\left(\beta_{0}+\beta_{1} \text { Cell phone owner }{ }_{i j t}+\delta X+\tau_{t}+U_{i}+\varepsilon_{i j t}\right) \\
& \operatorname{Pr}\left(\text { Entrepreneur }_{i j t}=1\right)=G\left(\beta_{0}+\beta_{1} \text { Social network }_{i j t}+\delta X+\tau_{t}+U_{i}+\varepsilon_{i j t}\right)
\end{aligned}
$$

where $U_{i}$ includes all the time-invariant individual-level unobservables. If this is the case, our previous results may be inefficient, if $U_{i}$ is uncorrelated with $X$, or biased, if $U_{i}$ is correlated with $X$. Since the two-year panel structure of the dataset used in this paper has little information variation over time but very large cross-section variation, the fixed-effects model that absorbs substantial cross-section heterogeneity will decrease the effectiveness of estimation (Kennedy, 2003). We therefore choose the random-effects model that is more efficient, when the panel dataset has a short time 
period but a large number of cross-section observations (Wilson and Butler, 2007; Disney and Gathergood, 2009).

Columns (1) to (3) of Table 8 report the results from equation ( $\left.1^{\prime}\right)$, and columns (4) to (6) display the results from equation (3'), based on the random-effects models. Results in column (1) to (3) show that after controlling for unobserved heterogeneity of individuals, cell phone owners are 1.3 percentage points more likely to become entrepreneurs than other groups. Results in column (4) to (6) show that internet users are 5.3 percentage points more likely to engage in entrepreneurship than the others. Hence, our previous conclusion that cell phone owners and internet users are associated with higher likelihood of becoming an entrepreneur is robust after controlling for unobserved heterogeneity of individuals.

\section{* Table 8 is inserted into here *}

\subsection{Model Misspecification}

Our previous estimations are based on a key identification assumption that the dependent variable has a linear relationship with the covariates. However, our previous estimators may be biased, if this assumption does not hold. In this section, we use the propensity score matching (PSM) approach to attenuate the concern of model misspecification. This approach estimates a propensity score for all individuals based on the "distance" between the treatment and control groups, and does not depend on the assumption of linear impacts of covariates (Kmenta, 2010).

In the PSM estimation, we use the nearest neighbor matching and kernel matching algorithm to match the people who do not use cell phone/internet, the comparison groups, with the people who use cell phone/internet, the treatment groups. The pair with 
closest propensity scores is matched. Then the Average Treatment effect on the Treated (ATT) is estimated by using the matched sample. The ATT has a similar interpretation as the marginal effect in the probit model by measuring the difference in the probability of transition to entrepreneurship between cell phone/internet users and the others.

The estimated ATTs, as reported in Table 9, are consistent with our previous results: cell phone owners are associated with a 2.8 3.1 percentage points higher probability of becoming entrepreneurs, and internet users are 7.3 percentage points more likely to engage in entrepreneurship relative to the others.

\section{* Table 9 is inserted into here *}

Below we use two approaches to check the matching quality of the PSM estimations. The first is to compare the distribution of the covariates in both the treatment and comparison groups before and after matching. As suggested by Rosenbaum and Rubin (1983), it is necessary to make sure that after matching the set of covariates is independent of the treatment effect. In other words, the distribution of covariates in both the treatment and comparison groups should be balanced after the matching procedure. The results of balancing test in Table 10 show that the difference in mean value of most covariates decreases dramatically and becomes statistically insignificant, suggesting a good quality of the matching. An exception is females, for whom the significance level is at the $10 \%$ level.

* Table 10 is inserted into here * 
We also check the common support condition that observations in the treatment group have comparison observations in the region of common support (Dehejia and Wahba, 2002). Matching incomparable observations can cause much larger estimation biases than selection on unobservables (Heckman, Ichimura and Todd, 1997). Hence, it is necessary to check the common support of the propensity scores for the treatment and comparison groups. The most straightforward way to check the common support condition is to analyze the density distribution of the propensity scores (Lechner, 2008). The propensity score distribution for the two groups, as displayed in Figure 3, provides supportive evidence of overlapping of the propensity score distributions. In summary, the two approaches both support reliability of our PSM estimation.

* Figure 3 is inserted into here *

\subsection{Reverse Causality of Entrepreneurship to ICT Utilization}

Since entrepreneurs are much more involved in business activities and need to acquire more information about the market, there can exist reverse causality between ICT utilization and entrepreneurship. To address this concern, we use the local cell phone ownership rate or internet usage rate to instrument for the individual-level cell phone ownership or internet use. This method is commonly used in the literature. See., e.g., DiPasquale and Glaeser (1999), Aaronson (2000), Harkness and Newman (2003), van Leuvensteijn and Koning (2004), and Munch, Rosholm and Svarer (2006).

Results based on the two-stage least squares (2SLS) model are reported in Table 11. We can see that after controlling for reverse causality of entrepreneurship to ICT utilization, the cell phone and internet users are associated with higher probability of being entrepreneurs than the others, and the differences are statistically significant at 
the $1 \%$ level. These results reinforce our previous finding that ICT utilization has a positive effect on entrepreneurship.

\section{* Table 11 is inserted into here *}

\section{Conclusions}

Given the important role of entrepreneurship to the economy and society, there is substantial interest in topics related to entrepreneurship. A vast body of literature examines the determinants of entrepreneurial ventures, but less attention has been paid to the utilization of information communication technology (ICT) and its relationship to entrepreneurship. This paper investigates whether ICT utilization increases an individual's probability of transition to entrepreneurship.

Using data from the China Family Panel Survey 2014 and 2016, we find that cell phone ownership and internet use have positive impacts on entrepreneurship. After controlling for observables, cell phone users (internet users) are 2.0 (6.4) percentage points more likely to engage in entrepreneurship than people who do not use them. Considering that the average entrepreneurship rate for rural households is only $9.5 \%$ in the sample, the influence of cell phone ownership and internet use is very large. Our results are robust to unobservable individual characteristics, model misspecification, and reverse causality of entrepreneurship to ICT utilization. Evidence also suggests that social networking and information acquisition play mediating roles in the impact of ICT utilization on entrepreneurship. The evidence of a positive effect of ICT utilization on entrepreneurship provides a new justification for policies or reforms intended to promote entrepreneurship by investment in ICT infrastructure, such as broadband construction in rural regions. 
A productive area for further research would be use or additional data to investigate whether the relationship between ICT utilization and entrepreneurship varies across different types of entrepreneurship. In addition, the current analysis only examines the impact of ICT utilization on the probability of transition to entrepreneurship. Whether and how ICT utilization affects entrepreneurial success, such as entrepreneurial profits and survival, also merits further investigation. While our cross section results are strong, even more dramatic results might be found by extending to nonlinear dynamical models capable of producing bifurcation. See Barnett and Chen (2015) regarding that research opportunity. 


\section{References}

Aaronson, D. (2000) 'A Note on the Benefits of Homeownership', Journal of Urban Economics, 47(3), pp. 356-369. doi: 10.1006/juec.1999.2144.

Acs, Z., Desai, S. and Hessels, J. (2008) ‘Entrepreneurship, Economic Development and Institutions', Small Business Economics, 31(3), pp. 219-234. doi: 10.1007/s11187008-9135-9.

Au, C.-C. and Henderson, V. (2006) ‘Are Chinese Cities Too Small?’, Review of Economic Studies, 73(3), pp. 549-576. doi: http://www.jstor.org/stable/20185020.

Bai, C., Lu, J. and Tao, Z. (2006) 'Property Rights Protection and Access to Bank Loans', The Economics of Transition, 14(4), pp. 611-628. doi: 10.1111/j.14680351.2006.00269.x.

Barnett, W. A. and Chen, G. (2015) 'Bifurcation of Macroeconometric Models and Robustness of Dynamical Inferences', Foundations and Trends in Econometrics, 8(12), pp. 1-144. doi: 10.1561/0800000026.

Blanchflower, D. and Oswald, A. (1998) 'What Makes an Entrepreneur?', Journal of Labor Economics, 16(1), pp. 26-60. doi: 10.1086/209881.

Carree, M. and Thurik, R. (2010) 'The Impact of Entrepreneurship on Economic Growth', in Handbook of Entrepreneurship Research. New York, NY: Springer, pp. 557-594. doi: 10.1007/978-1-4419-1191-9_20.

Chen, J. and Han, X. (2014) 'The Evolution of Housing Market and Its Socio-economic Impacts in Post-Reform China: A Survey of the Literature', Journal of Economic Surveys, 28(4), pp. 652-670. doi: 10.1111/joes.12076.

Cho, H., Gay, G., Davidson, B. and Ingraffea, A. (2007) 'Social Networks, Communication Styles, and Learning Performance in a CSCL Community’, Computers \& Education, 49(2), pp. 309-329. doi: 10.1016/j.compedu.2005.07.003. Chowdhury, F., Audretsch, D. and Belitski, M. (2015) 'Does Corruption Matter for International Entrepreneurship?', International Entrepreneurship and Management Journal, 11(4), pp. 959-980. doi: 10.1007/s11365-015-0372-5.

Companys, Y. E. and McMullen, J. S. (2007) 'Strategic Entrepreneurs at Work: The Nature, Discovery, and Exploitation of Entrepreneurial Opportunities', Small Business Economics, 28(4), pp. 301-322. doi: 10.1007/s11187-006-9034-х.

Cowling, M. and Taylor, M. (2001) 'Entrepreneurial Women and Men: Two Different Species?', Small Business Economics, 16(3), pp. 167-175. doi: 
10.1023/A:1011195516912.

Dehejia, R. and Wahba, S. (2002) 'Propensity Score-Matching Methods for Nonexperimental Causal Studies', Review of Economics and Statistics, 84(1), pp. 151-161. doi: 10.1162/003465302317331982.

DiPasquale, D. and Glaeser, E. (1999) 'Incentives and Social Capital: Are Homeowners Better Citizens?', Journal of Urban Economics, 45(2), pp. 354-384. doi: 10.1006/juec.1998.2098.

Disney, R. and Gathergood, J. (2009) 'Housing Wealth, Liquidity Constraints and Selfemployment', Labour Economics, 16(1), pp. 79-88. doi: http://dx.doi.org/10.1016/j.labeco.2008.05.002.

Djankov, S., Qian, Y., Roland, G. and Zhuravskaya, E. (2006) 'Who Are China’s Entrepreneurs?', American Economic Review, 96(2), pp. 348-352. Available at: http://www.jstor.org/stable/30034671.

Erwin, B., Turk, C., Heimberg, R., Fresco, D. and Hantula, D. (2004) 'The Internet: Home to a Severe Population of Individuals with Social Anxiety Disorder?', Journal of Anxiety Disorders, 18(5), pp. 629-646. doi: 10.1016/j.janxdis.2003.08.002.

Gibson, D., Kozmetsky, G. and Smilor, R. (1992) The Technopolis Phenomenon: Smart Cities, Fast Systems, Global Networks. Lanham, USA: Rowman \& Littlefield Publishers.

Glaeser, E., Huang, W., Ma, Y. and Shleifer, A. (2016) A Real Estate Boom with Chinese Characteristics. NBER Working Paper. Available at: http://www.nber.org/papers/w22789.

Gries, T. and Naudé, W. (2010) 'Entrepreneurship and Structural Economic Transformation', Small Business Economics, 34(1), pp. 13-29. doi: 10.1007/s11187009-9192-8.

Harkness, J. and Newman, S. (2003) 'Effects of Homeownership on Children: The Role of Neighborhood Characteristics and Family Income’, Economic Policy Review, (June), pp. 87-107. Available at: http://papers.ssrn.com/sol3/papers.cfm?abstract_id=790744. Heckman, J., Ichimura, H. and Todd, P. (1997) 'Matching As an Econometric Evaluation Estimator: Evidence from Evaluating a Job Training Programme', The Review of Economic Studies, 64(4), pp. 605-654. doi: 10.2307/2971733.

Holtz-Eakin, D., Joulfaian, D. and Rosen, H. (1994) 'Sticking it Out: Entrepreneurial Survival and Liquidity Constraints', Journal of Political Economy, 102(1), pp. 53-75. Hung, A., Parker, A. and Yoong, J. (2009) Defining and Measuring Financial Literacy. 
RAND Working Paper. doi: 10.2139/ssrn.1498674.

Karlan, D. and Valdivia, M. (2011) 'Teaching Entrepreneurship: Impact of Business

Training on Microfinance Clients and Institutions', Review of Economics and

Statistics, 93(2), pp. 510-527. doi: 10.1162/REST_a_00074.

Kennedy, P. (2003) A Guide to Econometrics. Cambridge, MA: The MIT Press.

Kmenta, J. (2010) ‘Mostly Harmless Econometrics: An Empiricist’s Companion',

Business Economics, 45(1), pp. 75-76. doi: 10.1057/be.2009.37.

Kozmetsky, G. (1985) Transformational Management. Cambridge, MA: Ballinger

Publishing Company.

Lechner, M. (2008) 'A Note on the Common Support Problem in Applied Evaluation

Studies', Annales d'Économie et de Statistique, (91/92), pp. 217-235. doi:

$10.2307 / 27917246$.

van Leuvensteijn, M. and Koning, P. (2004) 'The Effect of Home-ownership on Labor

Mobility in the Netherlands', Journal of Urban Economics, 55(3), pp. 580-596. doi:

10.1016/j.jue.2003.12.001.

Li, L. and Wu, X. (2014) 'Housing Price and Entrepreneurship in China', Journal of

Comparative Economics, 42(2), pp. 436-449. doi: 10.1016/j.jce.2013.09.001.

Meijers, H. (2014) 'Does the Internet Generate Economic Growth, International Trade, or Both?', International Economics and Economic Policy, 11(1), pp. 137-163. doi: 10.1007/s10368-013-0251-X.

Minniti, M. (2004) 'Entrepreneurial Alertness and Asymmetric Information in a Spinglass Model', Journal of Business Venturing, 19(5), pp. 637-658. doi:

10.1016/j.jbusvent.2003.09.003.

Munch, J. R., Rosholm, M. and Svarer, M. (2006) 'Are Homeowners Really More Unemployed?', The Economic Journal, 116(514), pp. 991-1013. doi: 10.1111/j.14680297.2006.01120.x.

Oseifuah, E. (2010) 'Financial Literacy and Youth Entrepreneurship in South Africa', African Journal of Economic and Management Studies. Edited by R. Rugimbana, 1(2), pp. 164-182. doi: 10.1108/20400701011073473.

Paulson, A. and Townsend, R. (2004) 'Entrepreneurship and Financial Constraints in Thailand', Journal of Corporate Finance, 10(2), pp. 229-262. Available at: http://www.sciencedirect.com/science/article/pii/S0929119903000567.

Pierce, T. (2009) 'Social Anxiety and Technology: Face-to-face Communication Versus Technological Communication among Teens’, Computers in Human Behavior, 25(6), 
pp. 1367-1372. doi: 10.1016/j.chb.2009.06.003.

Rosenbaum, P. R. and Rubin, D. B. (1983) 'The central role of the propensity score in observational studies for causal effects', Biometrika, 70(1), pp. 41-55. doi: 10.1093/biomet/70.1.41.

Schmalz, M., Sraer, D. and Thesmar, D. (2017) 'Housing Collateral and Entrepreneurship', The Journal of Finance, 72(1), pp. 99-132. doi: 10.1111/jofi.12468.

Schumpeter, J. A. (1951) Essays: on Entrepreneurs, Innovations, Business Cycle, and the Evolution of Capitalism. New York, NY: Transaction Publishers.

Shane, S. and Cable, D. (2002) 'Network Ties, Reputation, and the Financing of New Ventures', Management Science, 48(3), pp. 364-381. doi:

10.1287/mnsc.48.3.364.7731.

Shane, S. and Venkataraman, S. (2000) 'The Promise of Entrepreneurship as a Field of Research', The Academy of Management Review, 25(1), pp. 217-226. doi: 10.1007/978-3-540-48543-8_8.

Tang, M. and Coulson, E. (2017) 'The Impact of China’s Housing Provident Fund on Homeownership, Housing Consumption and Housing Investment', Regional Science and Urban Economics, 63, pp. 25-37. doi: 10.1016/j.regsciurbeco.2016.11.002.

Taylor, M. (2001) 'Self-Employment and Windfall Gains in Britain: Evidence from Panel Data’, Economica, 68(272), pp. 539-565. doi: 10.1111/1468-0335.00261.

Venkataraman, S. (1997) 'The Distinctive Domain of Entrepreneurship Research’, Advances in Entrepreneurship, Firm Emergence and Growth, 3(October), pp. 119138. doi: 10.2139/ssrn.1444184.

Wilson, S. and Butler, D. (2007) 'A Lot More to Do: The Sensitivity of Time-Series Cross-Section Analyses to Simple Alternative Specifications', Political Analysis, 15(2), pp. 101-123. doi: 10.1093/pan/mpl012.

Yoon, H., Yun, S., Lee, J. and Phillips, F. (2015) 'Entrepreneurship in East Asian Regional Innovation Systems: Role of Social Capital', Technological Forecasting and Social Change, 100, pp. 83-95. doi: 10.1016/j.techfore.2015.06.028.

Yueh, L. (2009) 'China’s Entrepreneurs’, World Development, 37(4), pp. 778-786. doi: 10.1016/j.worlddev.2008.07.010.

Zhang, Q. F. and Pan, Z. (2012) ‘Women’s Entry into Self-employment in Urban China: The Role of Family in Creating Gendered Mobility Patterns', World Development, 40(6), pp. 1201-1212. doi: 10.1016/j.worlddev.2011.11.004. 


\section{TABLES AND FIGURES}

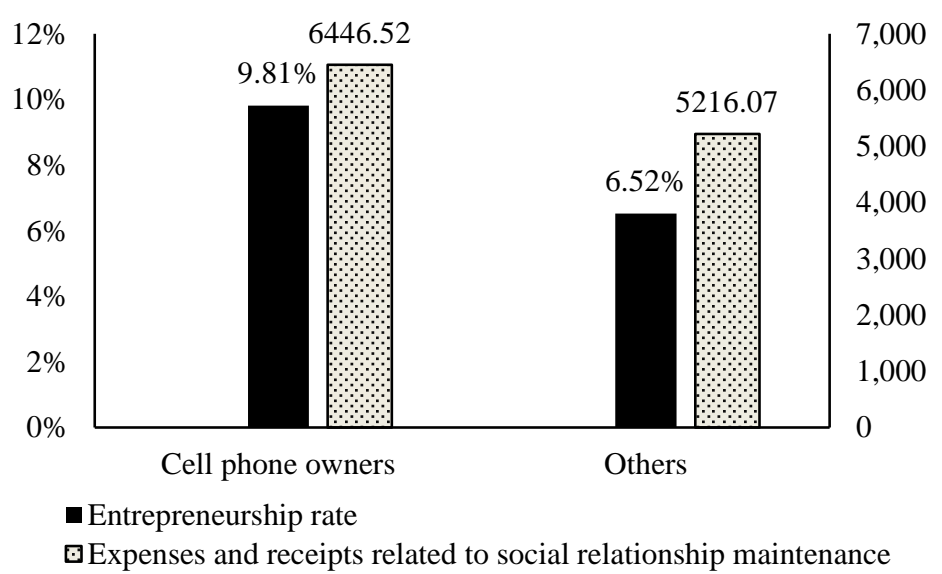

Data Source: China Family Panel Studies 2014 and 2016

\section{Figure 1 Cell phone ownership, social network and entrepreneurship rate}

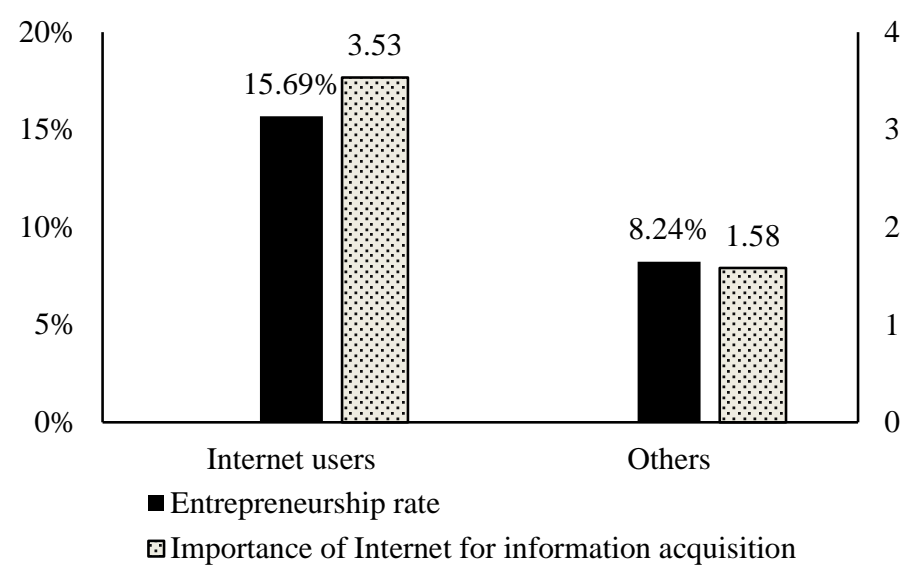

Data Source: China Family Panel Studies 2014 and 2016

Figure 2 Internet use, information and knowledge acquisition and entrepreneurship rate 


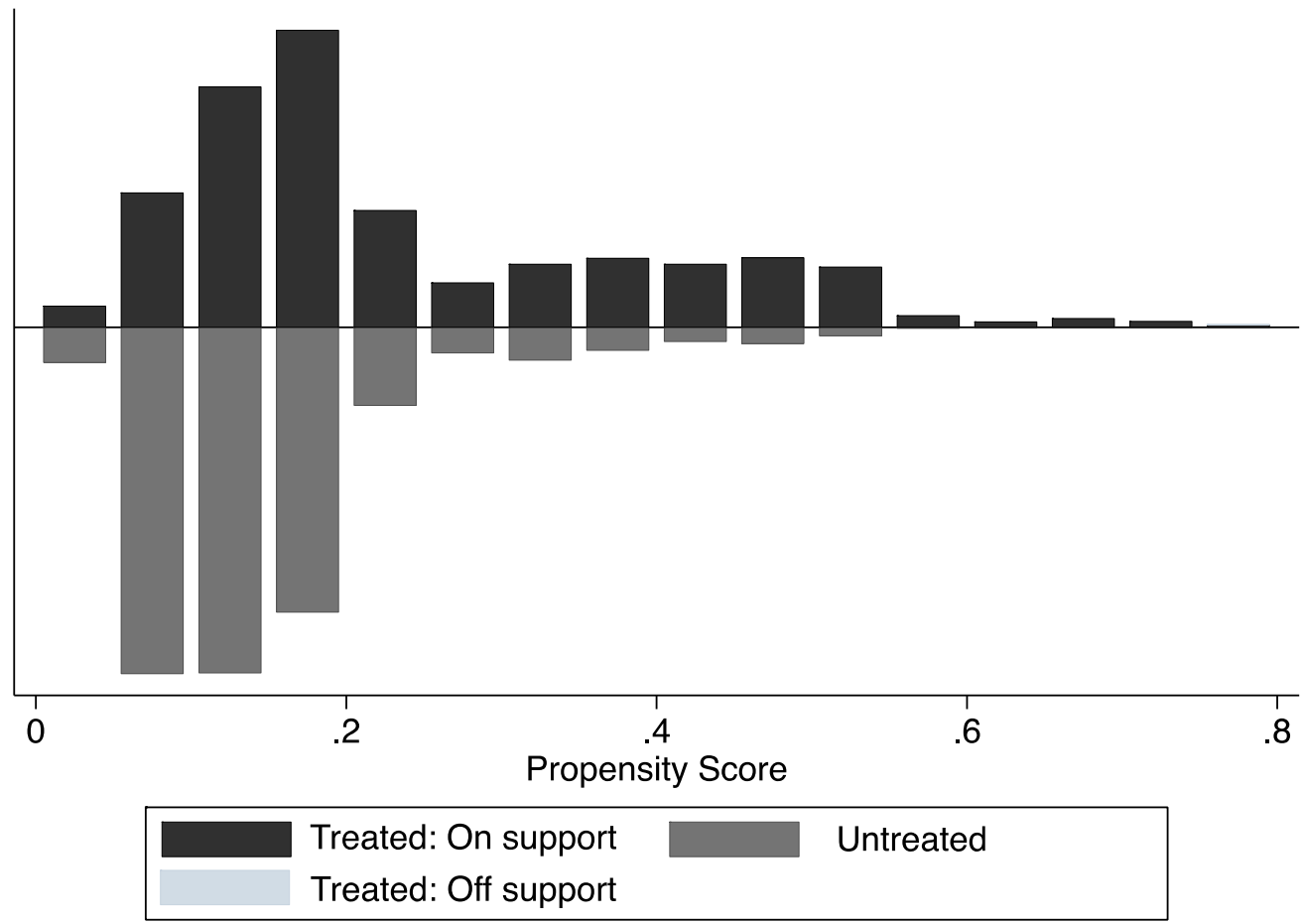

Figure 3 The propensity score distribution of the treatment and comparison groups 
Table 1 Descriptive statistics and definitions of variable

\begin{tabular}{|c|c|c|c|}
\hline Variables & Mean & Std.Dev. & Definitions \\
\hline \multicolumn{4}{|l|}{ Dependent variable } \\
\hline Entrepreneur & 0.095 & 0.293 & $\begin{array}{l}\text { An indicator variable of people who engage in self- } \\
\text { employed business or private enterprises }\end{array}$ \\
\hline \multicolumn{4}{|l|}{ Independent variables } \\
\hline Cell phone owner & 0.901 & 0.298 & An indicator variable of people who use cell phone \\
\hline Cell phone expenses & 49.46 & 48.49 & The mobile phone fee per month (yuan) \\
\hline Internet user & 0.167 & 0.373 & An indicator variable of people who use the internet \\
\hline \multicolumn{4}{|l|}{ Mediating variables } \\
\hline Social network & 6,325 & 11,508 & $\begin{array}{l}\text { The total amount of expenses and receipts related to the } \\
\text { maintenance of social relations in the last year (yuan) }\end{array}$ \\
\hline Information acquisition & 1.907 & 1.484 & $\begin{array}{l}\text { The importance of the internet for information and } \\
\text { knowledge acquisition (1-5 scale: } 1 \text { is very unimportant } \\
\text { and } 5 \text { is very important) }\end{array}$ \\
\hline \multicolumn{4}{|l|}{ Control variables } \\
\hline College & 0.033 & 0.178 & $\begin{array}{l}\text { An indicator variable of people having a college degree or } \\
\text { higher }\end{array}$ \\
\hline Age & 42.89 & 11.47 & The age of people \\
\hline Married & 0.880 & 0.325 & An indicator variable of people being married \\
\hline Female & 0.508 & 0.500 & An indicator variable of people being female \\
\hline Urban hukou & 0.056 & 0.230 & An indicator variable of people having an urban hukou \\
\hline Communist & 0.471 & 0.499 & $\begin{array}{l}\text { An indicator variable of a member of Chinese Communist } \\
\text { Party (CCP) }\end{array}$ \\
\hline Household wealth & 165,805 & 254,739 & $\begin{array}{l}\text { The total amount of household wealth: the sum of financial } \\
\text { wealth, deposit and housing wealth (yuan) }\end{array}$ \\
\hline Observation & \multicolumn{2}{|c|}{15,702} & \\
\hline
\end{tabular}

Note:

1). We restrict the sample to working adults aged between 20 and 60 years old because analysis in this paper focuses on individual's working choice;

2). Data source: China Family Panel Studies 2014 and 2016. 
Table 2 Cell phone ownership and entrepreneurship (estimated by probit models)

\begin{tabular}{|c|c|c|c|c|c|c|c|c|}
\hline & \multicolumn{2}{|c|}{$(1)$} & \multicolumn{2}{|c|}{$(2)$} & \multicolumn{2}{|c|}{ (3) } & \multicolumn{2}{|c|}{ (4) } \\
\hline & Coef. & $\begin{array}{l}\text { Marginal } \\
\text { Effect }\end{array}$ & Coef. & $\begin{array}{l}\text { Marginal } \\
\text { Effect }\end{array}$ & Coef. & $\begin{array}{l}\text { Marginal } \\
\text { Effect }\end{array}$ & Coef. & $\begin{array}{l}\text { Marginal } \\
\text { Effect }\end{array}$ \\
\hline \multirow[t]{2}{*}{ Cell phone owner } & $0.220 * * *$ & 0.033 & $0.143 * * *$ & 0.022 & $0.137 * *$ & $0.020 * * *$ & & \\
\hline & $(0.051)$ & & $(0.053)$ & & $(0.055)$ & & & \\
\hline \multirow{2}{*}{\multicolumn{3}{|c|}{ Log(Cell phone expenses) }} & & & & & $0.157 * * *$ & 0.025 \\
\hline & & & & & & & $(0.026)$ & \\
\hline \multirow[t]{2}{*}{ College } & & & $0.201 * * *$ & 0.037 & $0.209 * *$ & $0.037 * *$ & $0.204 * *$ & 0.037 \\
\hline & & & $(0.070)$ & & $(0.083)$ & & $(0.087)$ & \\
\hline \multirow[t]{2}{*}{ Age } & & & -0.005 & -0.001 & -0.001 & -0.000 & 0.001 & 0.000 \\
\hline & & & $(0.009)$ & & $(0.010)$ & & $(0.010)$ & \\
\hline \multirow[t]{2}{*}{ Age squared } & & & -0.000 & -0.000 & -0.000 & -0.000 & -0.000 & -0.000 \\
\hline & & & $(0.000)$ & & $(0.000)$ & & $(0.000)$ & \\
\hline \multirow[t]{2}{*}{ Married } & & & $0.173^{* * *}$ & 0.026 & $0.144 * * *$ & $0.021 * * *$ & $0.167 * * *$ & 0.024 \\
\hline & & & $(0.050)$ & & $(0.050)$ & & $(0.052)$ & \\
\hline \multirow[t]{2}{*}{ Female } & & & -0.022 & -0.004 & -0.022 & -0.004 & 0.026 & 0.004 \\
\hline & & & $(0.028)$ & & $(0.029)$ & & $(0.030)$ & \\
\hline \multirow[t]{2}{*}{ Urban hukou } & & & $0.242 * * *$ & 0.045 & $0.323 * * *$ & $0.061^{* * *}$ & $0.284 * * *$ & 0.054 \\
\hline & & & $(0.055)$ & & $(0.057)$ & & $(0.059)$ & \\
\hline \multirow[t]{2}{*}{ Communist } & & & $-0.112 * * *$ & -0.018 & $-0.096 *$ & $-0.015 *$ & $-0.108 *$ & -0.017 \\
\hline & & & $(0.028)$ & & $(0.054)$ & & $(0.057)$ & \\
\hline \multirow{2}{*}{\multicolumn{3}{|c|}{ Log(Household wealth) }} & $0.051 * * *$ & 0.008 & $0.043^{* * *}$ & $0.007 * * *$ & $0.042 * * *$ & 0.007 \\
\hline & & & $(0.009)$ & & $(0.008)$ & & $(0.008)$ & \\
\hline Year dummies & \multicolumn{2}{|c|}{ No } & \multicolumn{2}{|c|}{ No } & \multicolumn{2}{|c|}{ Yes } & \multicolumn{2}{|c|}{ Yes } \\
\hline Location dummies & \multicolumn{2}{|c|}{ No } & \multicolumn{2}{|c|}{ No } & \multicolumn{2}{|c|}{ Yes } & \multicolumn{2}{|c|}{ Yes } \\
\hline Pseudo R-squared & \multicolumn{2}{|c|}{0.002} & \multicolumn{2}{|c|}{0.019} & \multicolumn{2}{|c|}{0.044} & \multicolumn{2}{|c|}{0.049} \\
\hline Observations & \multicolumn{2}{|c|}{15,702} & \multicolumn{2}{|c|}{15,702} & \multicolumn{2}{|c|}{15,702} & \multicolumn{2}{|c|}{14,154} \\
\hline $\begin{array}{l}\text { Note: } \\
\text { 1). The depender } \\
\text { 2). * p }<0.1 \text {, ** } \\
\text { 3). Robust stand } \\
\text { 4). The marginal } \\
0 \text { to } 1 \text {; } \\
\text { 5). Column (1) t } \\
\text { phone users. }\end{array}$ & $\begin{array}{l}\text { variable i } \\
<0.05, * \\
\text { d errors a } \\
\text { ffect of a } \\
\text { (3) presen }\end{array}$ & $\begin{array}{l}\text { n indicator } \\
\mathrm{p}<0.01 \text {; } \\
\text { given in par } \\
\text { mmy variab }\end{array}$ & $\begin{array}{l}\text { f entreprene } \\
\text { e meses; } \\
\text { sed on the fures }\end{array}$ & $\begin{array}{l}\text { r; } \\
\text { e impact o } \\
\text { sample, } \mathrm{w}\end{array}$ & $\begin{array}{l}\text { discrete } \\
\text { le the sam }\end{array}$ & $\begin{array}{l}\text { ange of the } \\
\text { e in column }\end{array}$ & $\begin{array}{l}\text { mmy varia } \\
\text { 4) is limite }\end{array}$ & $\begin{array}{l}\text { le from } \\
\text { to cell }\end{array}$ \\
\hline
\end{tabular}


Table 3 Cell phone ownership and social network (estimated by OLS models)

\begin{tabular}{llll}
\hline & $(1)$ & $(2)$ & $(3)$ \\
\hline Cell phone owner & $0.272^{* * *}$ & $0.214^{* * *}$ & $0.229^{* * *}$ \\
& $(0.044)$ & $(0.045)$ & $(0.044)$ \\
\hline Control variables & No & Yes & Yes \\
Year dummies & No & No & Yes \\
Location dummies & No & No & Yes \\
R-squared & 0.003 & 0.024 & 0.112 \\
Observations & 15,702 & 15,702 & 15,702 \\
\hline
\end{tabular}

Note:

1). The dependent variable is the log value of the total amount of expenses and receipts related to social relationship maintenance;

2). ${ }^{*} \mathrm{p}<0.1,{ }^{* *} \mathrm{p}<0.05,{ }^{* * *} \mathrm{p}<0.01$;

3). Robust standard errors are given in parentheses;

4). Control variables include education, age, marital status, gender, hukou, political status, and household wealth. 
Table 4 Social network and entrepreneurship (estimated by probit models)

\begin{tabular}{|c|c|c|c|c|c|c|}
\hline & \multicolumn{2}{|c|}{ (1) } & \multicolumn{2}{|c|}{$(2)$} & \multicolumn{2}{|c|}{ (3) } \\
\hline & Coef. & $\begin{array}{l}\text { Marginal } \\
\text { Effect }\end{array}$ & Coef. & $\begin{array}{l}\text { Marginal } \\
\text { Effect }\end{array}$ & Coef. & $\begin{array}{l}\text { Marginal } \\
\text { Effect }\end{array}$ \\
\hline Social network & $\begin{array}{l}0.093 * * * \\
(0.011)\end{array}$ & 0.015 & $\begin{array}{l}0.080 * * * \\
(0.011)\end{array}$ & 0.013 & $\begin{array}{l}0.089 * * * \\
(0.012)\end{array}$ & 0.014 \\
\hline Control variables & \multicolumn{2}{|c|}{ No } & \multicolumn{2}{|c|}{ Yes } & \multicolumn{2}{|c|}{ Yes } \\
\hline Year dummies & \multicolumn{2}{|c|}{ No } & \multicolumn{2}{|c|}{ No } & \multicolumn{2}{|c|}{ Yes } \\
\hline Location dummies & \multicolumn{2}{|c|}{ No } & \multicolumn{2}{|c|}{ No } & \multicolumn{2}{|c|}{ Yes } \\
\hline Pseudo R-squared & \multicolumn{2}{|c|}{0.010} & \multicolumn{2}{|c|}{0.025} & \multicolumn{2}{|c|}{0.051} \\
\hline Observations & \multicolumn{2}{|c|}{15,702} & \multicolumn{2}{|c|}{15,702} & \multicolumn{2}{|c|}{15,702} \\
\hline
\end{tabular}

\section{Note:}

1). The dependent variable is an indicator of entrepreneur;

2). $* \mathrm{p}<0.1, * * \mathrm{p}<0.05, * * * \mathrm{p}<0.01$;

3). Robust standard errors are given in parentheses;

4). Control variables include education, age, marital status, gender, hukou, political status, and household wealth;

4). The marginal effect of a dummy variable measures the impact of a discrete change of the dummy variable from 0 to 1 . 
Table 5 Internet use and entrepreneurship (estimated by probit models)

\begin{tabular}{lcccccc}
\hline & \multicolumn{2}{c}{$(1)$} & \multicolumn{2}{c}{$(2)$} & \multicolumn{2}{c}{ (3) } \\
\cline { 2 - 6 } & Coef. & $\begin{array}{l}\text { Marginal } \\
\text { Effect }\end{array}$ & Coef. & $\begin{array}{l}\text { Marginal } \\
\text { Effect }\end{array}$ & Coef. & $\begin{array}{l}\text { Marginal } \\
\text { Effect }\end{array}$ \\
\hline Internet user & $0.382^{* * *}$ & 0.074 & $0.404^{* * *}$ & 0.078 & $0.350^{* * *}$ & 0.064 \\
& $(0.034)$ & & $(0.042)$ & & $(0.043)$ & \\
\hline Control variables & No & Yes & Yes \\
Year dummies & No & No & Yes \\
Location dummies & No & No & Yes \\
Pseudo R-squared & 0.010 & 0.025 & 0.051 \\
Observations & 15,702 & 15,702 & 15,702 \\
\hline Note:
\end{tabular}

\section{Note:}

1). The dependent variable is an indicator of entrepreneur;

2). $* \mathrm{p}<0.1, * * \mathrm{p}<0.05, * * * \mathrm{p}<0.01$;

3). Robust standard errors are given in parentheses;

4). Control variables include education, age, marital status, gender, hukou, political status, and household wealth;

4). The marginal effect of a dummy variable measures the impact of a discrete change of the dummy variable from 0 to 1 . 
Table 6 Cell phone ownership and information acquisition (estimated by OLS models)

\begin{tabular}{llll}
\hline & $(1)$ & $(2)$ & $(3)$ \\
\hline Cell phone owner & $0.272^{* * *}$ & $0.214^{* * *}$ & $0.229^{* * *}$ \\
& $(0.044)$ & $(0.045)$ & $(0.044)$ \\
\hline Control variables & No & Yes & Yes \\
Year dummies & No & No & Yes \\
Location dummies & No & No & Yes \\
R-squared & 0.003 & 0.024 & 0.112 \\
Observations & 15,702 & 15,702 & 15,702 \\
\hline
\end{tabular}

Note:

1). The dependent variable is the importance of the internet for information and knowledge acquisition (1-5 scale: 1 is very unimportant and 5 is very important);

2). ${ }^{*} \mathrm{p}<0.1, * * \mathrm{p}<0.05,{ }^{* * *} \mathrm{p}<0.01$;

3). Robust standard errors are given in parentheses;

4). Control variables include education, age, marital status, gender, hukou, political status, and household wealth. 
Table 7 Information acquisition and entrepreneurship (estimated by probit models)

\begin{tabular}{lcccccc}
\hline & \multicolumn{2}{c}{$(1)$} & \multicolumn{2}{c}{$(2)$} & \multicolumn{2}{c}{ (3) } \\
\cline { 2 - 6 } & Coef. & $\begin{array}{l}\text { Marginal } \\
\text { Effect }\end{array}$ & Coef. & $\begin{array}{l}\text { Marginal } \\
\text { Effect }\end{array}$ & Coef. & $\begin{array}{l}\text { Marginal } \\
\text { Effect }\end{array}$ \\
\hline Information acquisition & $\begin{array}{l}0.382^{* * *} \\
(0.034)\end{array}$ & 0.074 & $0.404^{* * *}$ & 0.078 & $0.350^{* * *}$ & 0.064 \\
& & $(0.042)$ & & $(0.043)$ & \\
\hline Control variables & No & Yes & Yes \\
Year dummies & No & No & Yes \\
Location dummies & No & No & Yes \\
Pseudo R-squared & 0.010 & 0.025 & 0.051 \\
Observations & 15,702 & 15,702 & 15,702 \\
\hline Note:
\end{tabular}

\section{Note:}

1). The dependent variable is an indicator of entrepreneur;

2). $* \mathrm{p}<0.1, * * \mathrm{p}<0.05, * * * \mathrm{p}<0.01$;

3). Robust standard errors are given in parentheses;

4). Control variables include education, age, marital status, gender, hukou, political status, and household wealth;

4). The marginal effect of a dummy variable measures the impact of a discrete change of the dummy variable from 0 to 1 . 
Table 8 Cell phone ownership, internet use and entrepreneurship (estimated by random-effects models)

\begin{tabular}{|c|c|c|c|c|c|c|}
\hline & \multicolumn{3}{|c|}{ Cell phone ownership and entrepreneurship } & \multicolumn{3}{|c|}{ Internet use and entrepreneurship } \\
\hline & $(1)$ & $(2)$ & $(3)$ & $(4)$ & $(5)$ & $(6)$ \\
\hline \multirow[t]{2}{*}{ Cell phone owner } & $0.025 * * *$ & $0.015^{* *}$ & $0.013^{*}$ & & & \\
\hline & $(0.007)$ & $(0.007)$ & $(0.007)$ & & & \\
\hline \multirow[t]{2}{*}{ Internet user } & & & & $0.055 * * *$ & $0.060 * * *$ & $0.053 * * *$ \\
\hline & & & & $(0.008)$ & $(0.009)$ & $(0.009)$ \\
\hline Control variables & No & Yes & Yes & No & Yes & Yes \\
\hline Year dummies & No & No & Yes & No & No & Yes \\
\hline Location dummies & No & No & Yes & No & No & Yes \\
\hline Within R-squared & 0.0000 & 0.0010 & 0.0010 & 0.0001 & 0.0015 & 0.0016 \\
\hline Observations & 15,702 & 15,702 & 15,702 & 15,702 & 15,702 & 15,702 \\
\hline
\end{tabular}

Note:

1). The dependent variable is an indicator of entrepreneur;

2). * $\mathrm{p}<0.1$, ** $\mathrm{p}<0.05$, *** $\mathrm{p}<0.01$;

3). Robust standard errors are given in parentheses;

4). Control variables include education, age, marital status, gender, hukou, political status, and household wealth. 
Table 9 Cell phone ownership, internet use and entrepreneurship (estimated by PSM methods)

\begin{tabular}{lllll}
\hline & \multicolumn{2}{c}{ Nearest neighbor matching } & \multicolumn{2}{c}{ Kernel matching } \\
\cline { 2 - 5 } & $(1)$ & $(2)$ & $(3)$ & $(4)$ \\
\hline Cell phone owner & $0.028^{* * *}$ & & $0.031^{* * *}$ & \\
& $(0.008)$ & & $(0.008)$ & \\
Internet user & & $0.073^{* * *}$ & & $0.073^{* * *}$ \\
& & $(0.008)$ & & $(0.008)$ \\
\hline Control variables & Yes & Yes & Yes & Yes \\
Year dummies & Yes & Yes & Yes & Yes \\
County dummies & Yes & Yes & Yes & Yes \\
Observations & 15,702 & 15,702 & 15,702 & 15,702 \\
\hline
\end{tabular}

Note:

1). The dependent variable is an indicator of entrepreneur;

2). ${ }^{*} \mathrm{p}<0.1, * * \mathrm{p}<0.05$, *** $\mathrm{p}<0.01$;

3). Robust standard errors are given in parentheses;

4). Control variables include education, age, marital status, gender, hukou, political status, and household wealth. 
Table 10 Balancing quality of kernel matching

\begin{tabular}{|c|c|c|c|c|c|c|}
\hline & & \multicolumn{2}{|c|}{ Mean } & \multirow{2}{*}{$\begin{array}{l}\text { The } \\
\text { differences }\end{array}$} & \multirow{2}{*}{ t vales } & \multirow{2}{*}{$\mathrm{p}$ values } \\
\hline & & Treated & Control & & & \\
\hline \multirow[t]{2}{*}{ Education } & Unmatched & 3.830 & 3.704 & 13.700 & 6.420 & 0.000 \\
\hline & Matched & 3.829 & 3.818 & 1.200 & 91.300 & 0.420 \\
\hline \multirow[t]{2}{*}{ Married } & Unmatched & 0.717 & 0.912 & -51.800 & -28.700 & 0.000 \\
\hline & Matched & 0.717 & 0.722 & -1.200 & 97.800 & -0.350 \\
\hline \multirow[t]{2}{*}{ Female } & Unmatched & 0.433 & 0.522 & -18.000 & -8.400 & 0.000 \\
\hline & Matched & 0.433 & 0.434 & -0.200 & 99.100 & -0.060 \\
\hline \multirow[t]{2}{*}{ Urban hukou } & Unmatched & 0.111 & 0.045 & 24.600 & 13.350 & 0.000 \\
\hline & Matched & 0.110 & 0.104 & 2.500 & 90.000 & 0.770 \\
\hline \multirow[t]{2}{*}{ Communist } & Unmatched & 0.595 & 0.446 & 30.000 & 13.970 & 0.000 \\
\hline & Matched & 0.595 & 0.592 & 0.500 & 98.300 & 0.180 \\
\hline \multirow[t]{2}{*}{$\log$ (Household wealth) } & Unmatched & 11.391 & 10.852 & 21.100 & 9.570 & 0.000 \\
\hline & Matched & 11.390 & 11.306 & 3.300 & 84.400 & 1.390 \\
\hline
\end{tabular}

Note: The differences refer to the mean value differences between the treatment and control groups. 
Table 11 Cell phone ownership, internet use and entrepreneurship

(estimated by IV models)

\begin{tabular}{|c|c|c|c|c|c|c|}
\hline & \multicolumn{3}{|c|}{ Cell phone ownership and entrepreneurship } & \multicolumn{3}{|c|}{ Internet use and entrepreneurship } \\
\hline & $(1)$ & $(2)$ & (3) & (4) & (5) & $(6)$ \\
\hline \multirow[t]{2}{*}{ Cell phone owner } & $0.145^{* * *}$ & $0.122^{* * *}$ & $0.133^{* * *}$ & & & \\
\hline & $(0.023)$ & $(0.022)$ & $(0.030)$ & & & \\
\hline \multirow[t]{2}{*}{ Internet user } & & & & $0.234^{* * *}$ & $0.288 * * *$ & $0.244 * * *$ \\
\hline & & & & $(0.024)$ & $(0.029)$ & $(0.036)$ \\
\hline Control variables & No & Yes & Yes & No & Yes & Yes \\
\hline Year dummies & No & No & Yes & No & No & Yes \\
\hline Location dummies & No & No & Yes & No & No & Yes \\
\hline Wald chi2 & 41.140 & 180.05 & 379.99 & 91.220 & 235.22 & 394.79 \\
\hline Observations & 15,702 & 15,702 & 15,702 & 15,702 & 15,702 & 15,702 \\
\hline
\end{tabular}

1). The dependent variable is an indicator of entrepreneur;

2). $* \mathrm{p}<0.1, * * \mathrm{p}<0.05$, *** $\mathrm{p}<0.01$;

3). Robust standard errors are given in parentheses;

4). Control variables include education, age, marital status, gender, hukou, political status, and household wealth. 